\title{
Influence of Coronavirus on Consumer Behaviour in the Ecological Context
}

\author{
Wpływ koronawirusa na zachowania konsumencie w kontekście ekologicznym
}

\author{
Andrea Seberíni \\ Faculty of Economics, Matej Bel University in Banská Bystrica, Slovakia \\ ORCID: https://orcid.org/0000-0002-8531-1611•andrea.seberini@umb.sk \\ Received: 02 Sep 2020; Revised: 29 Nov 2020; Accepted: 10 Dec 2020
}

\begin{abstract}
The COVID-19 pandemic has fundamentally changed the world as we know it. People are living differently, buying differently and in many ways, thinking differently. This study takes the lead of research by trying to answer the following research question: How does the coronavirus impact consumer behaviour in the ecological context? The paper begins with a presentation of the concept of consumer behaviour, its theoretical background and definition, and then discusses the question of the pandemic and its socio-economic effects on the consumer. Next, the paper presents a study on consumer behaviour in the era of the pandemic. Finally, it analyses the impact of consumer behaviour in the era of the pandemic on the environment.
\end{abstract}

Keywords: Coronavirus (Covid 19), consumer behaviour, environmental impact

Streszczenie: Pandemia COVID-19 istotnie zmieniła świat, jaki znamy. Ludzie żyją inaczej, inaczej kupują i na wiele sposobów, inaczej myślą. Niniejszy artykuł jest początkiem badań, mających na celu znalezienie odpowiedzi na następujące pytanie badawcze: Jak koronawirus wpływa na zachowania konsumenckie w kontekście ekologicznym? Artykuł rozpoczyna się od prezentacji zjawiska zachowań konsumenckich, podstaw teoretycznych i definicji tego zjawiska, omawia też kwestię pandemii i jej społeczno-ekonomiczne skutki. Następnie opracowanie to prezentuje wyniki badań na temat zachowań konsumentów w dobie pandemii, by ostatecznie dokonać analizy wpływu zachowań konsumenckich na środowisko w tym okresie.

Słowa kluczowe: koronawirus (Covid 19), zachowania konsumenckie, wpływ na środowisko 


\section{Introduction}

The COVID-19 global pandemic is having a profound impact on consumers' lives. As stay-at-home orders and country-wide lockdowns start to be eased, consumer behaviour continues to be driven by new personal circumstances, such as changes in discretionary income and spare time, and reconsidered values and priorities. In the centre of attention is the consumer behaviour. The behaviour of the customer is also considered as an independent variable. The main reason behind its independence is that the way the population will act in response to the pandemic of COVID - 19 (Liang and Litscher 2020). The purpose of this research paper is to examine the impact of Covid-19 pandemic on consumer behaviour.

This study takes the lead of research by trying to answer the following research question: How does the coronavirus impact consumer behaviour in the ecological context? The paper begins with a presentation of the concept of consumer behaviour, its theoretical background and definition, and then discusses the question of the pandemic and its socio-economic effects on the consumer. Next, the paper presents a study on consumer behaviour in the era of the pandemic. Finally, it analyses the impact of consumer behaviour in the era of the pandemic on the environment.

The reason why this study considers it important to pay attention to consumer buying behaviour, is that the way the customers choose their products and services can be important for manufacturers as well as service providers as this provides them with competitive advantage over its competitors in several aspects.

\section{Methodology}

The aims of this review are to provide a comprehensive and systematic overview. The methodology for this overview of systematic review was based on the framework outlined by Arksey and O'Malley (2005) with the recommendations made by Levac et al. (2010) and Peters et al. (2015). Systematic literature reviews, which are becoming more and more popular in academic research, rely on a rigorous, robust, clearly defined and reliable literature search and selection methodology that enables the reader to reproduce sample generation and evaluation (Levac et al. 2010).

The review included the five key phases on recommendation made by Arksey and O'Malley (2005): (1) identifying the research question, (2) identifying relevant studies, (3) study selection, (4) charting the data, and (5) collating, summarizing, and reporting the results; the optional 'consultation exercise' of the framework was not conducted. Moreover, as suggested by Levac et al. (2010), this review: a) used an interactive team approach to selecting and extracting studies, b) incorporated an essential numerical summary and a qualitative analysis of the contributions extracted, and c) identified the implication of the study findings for policy and practice.

Relevant sources were searched via four scientific databases: Web of Science (112), Pubmed (41), Idunn (6), SocIndex (55). The search was performed based on the Keywords: gambling, elderly, older adults, seniors, old people using the Boolean operators "and" and "or". Further keywords included: Europe, Norway, Czech Republic, Slovak Republic. The language of the papers was English, Czech and Slovak. Qualitative and quantitative articles of any study type were included.

During the first phase of the search, 214 studies were found, followed by filtering the results to achieve the number of 146 . In the next phase of the analysis, all duplicates and studies that did not deal with the discussed issues were rejected. Results older than 10 years and works for which did not have the opportunity to obtain the full published version were also excluded. The number of publications used to prepare our review study was 64 . The final number of works used to process our review study was 42 . Collection and analysis of results took place 
in the period from June to September 2020. The database search was complemented by an additional forward and backward snowball search.

Each paper identified during the search was first evaluated for possible relevance based on its title and abstract. Subsequently, all works that remained in the initial working sample were completely read to assess their relevance for this study based on the defined selection criteria and the purpose of the investigation. Works contained in the final sample are analysed and discussed in the following section.

\section{Consumer behaviour}

In this part of the study, we consider it essential to clarify consumer behaviour from the point of view of several definitions of authors and discussion about them. For many years, consumers and their behaviour have been researched both in science and in practice. Moreover, the following popular definitions have been proposed for the term of consumer buyer behaviour. According to Blackwell et al. (2006) consumer buying behaviour is itself is a complex, dynamic issue which cannot be defined easily and commonly. Therefore, the concept of consumer buying behaviour has been defined in different ways by different researchers. The definition formed by Solomon (2011) describes consumer buying behaviour as a process of choosing, purchasing, using and disposing of products or services by individuals and groups in order to satisfy their needs and wants. Similar definition of consumer buying behaviour is offered by Schiffman et al. (2008) in which they describe it as behaviour that consumers express when they select and purchase the products or services using their available resources in order to satisfy their needs and desires. Consumer buying behaviour is defined by Stallworth (2008) as a set of activities which involve the purchase and use of goods and services resulting from the customers' emotional and mental needs and behavioural responses. It is further stated by Salomon et al. (2016) that the process may encompass different activities and stages. Although the definitions given above differ, they all lead to the common view that consumer buying behaviour is a process of selecting, purchasing, and disposing of goods and services according to the needs and wants of consumers. However, there seems to be in the above definitions a general consensus on the subject of constant change at a time when the purchasing characteristics of customers change due to their physical and psychological needs. The approaches explaining consumer behaviour are divided into three groups (Valaskova et al. 2015): psychical-based on the relation between the psyche and behaviour of the consumer; sociological approach - which is devoted to the reactions of consumers in different situations or the ways in which the behaviours are influenced by various social circumstances, social leaders; and economic approach-grounded on the basic knowledge of micro economy in which consumers define their requirements. Subsequently, the consumer interests are confronted and traded on the market.

As research shows, there are many different theories and models used to explain why consumers act as they do. Consumer behaviour is the study of how individuals, groups, and collective entities choose, purchase, utilize, and discard ideas, goods, or services to satisfy their needs and wants. The relationship between the customer (also called the buyer) and the provider (the seller) forms through a phenomenon called market exchange (Vysekalová 2011). During the exchange process, each party assesses the relative trade-offs they must make to satisfy their respective needs and wants. On the part of the seller, the tradeoffs are guided by company policies and objectives. The consumer is stimulated by stimulus (Stimulus Input Variable), which are based on the quality, price, individuality and availability of the product or service. Externally variable as a family, belonging to a social class, time pressure, the financial situation affects shopping behaviour as 
an influence of the social environment (environment). Finally, the consumer's behaviour is expressed by a step-by-step process (Output - Variable) starting with attention (leading to attention), leading through purchasing intentions to the purchase itself (Vysekalová 2011).

All the arguments stated above lead to the conclusion that better understanding of the consumer buying behaviour through studying and identifying their needs leads to huge long-term benefits to the businesses and environment as well. However, as stated by Salomon et al (2016), it is essential to mention that despite the great efforts to learn and understand the buying behaviour of consumers, it is very difficult to identify the exact reasons why a consumer purchases and prefers one product or service over another one. This is because consumers sometimes make purchasing decisions based on their emotions. This paper focused to clarify consumer behaviour, which later applies to consumer behaviour in the environmental context.

\section{Coronavirus pandemic situation and its socio-economic effect}

In this section, we discuss how the pandemic affected the socio-economic effect. We start by discussing the coronavirus pandemic situation, then the short-term social and economic effects.

Since its outbreak in Wuhan (China) in November 2019, the COVID-19 strain of the novel coronavirus spread rapidly across China and beyond to affect 200 countries with tragic consequences - over 3 million cases (over 1.4 million in Europe alone) of reported infections with in excess of 190,000 people dead by the end of April of 2020 (WHO 2020). This has had a major impact on consumers and the retail sector across Europe and further afield (Feng and Fay 2020; Evans 2020). As a response to the initial outbreak, China was the first country in the world to impose a mandatory nationwide self-quarantine between 23 January and 9 February 2020 (Bloomberg News
2020). Since then, many other countries in Europe and in the rest of the world have followed suit by issuing restrictions to their citizens' movements in order to stop the spread of the virus (Chinazzi et al. 202O; Hedgecoe et al. 202O). In order to counteract the expansion of the Coronavirus, schools and universities were closed in many countries around the globe, events were cancelled and retailers that did not sell essential products had to close, while supermarkets remained open. Changes were introduced in most countries quite quickly and drastically, however, countries across the globe have taken different measures such as quarantine rules, curfews, and border closures (Graham-Harrison 2020).

COVID-19 not only seriously endangers people's life safety and health but also greatly affects economic globalization. To address the challenges posed by the coronavirus and to suggest better strategies for predicting, preventing, coping with and mitigating the associated challenges, it is necessary to understand the socio-economic and climatic factors. Simultaneously, given that the climate and socio-economic context are unlikely to change in the short term, it is easier to intervene accordingly (Schneide and Gustavo 2018). However, research on the climatic and socio-economic drivers of COVID-19 transmission is still insufficient, especially regarding the effects of socioeconomic factors and total effects of socioecological factors. Ignoring important non-climatic factors or other confounding factors (such as the economic growth, poverty, health, infrastructure, science and technology, social security, and labour) would overestimate the effects of climate change. The socio-economic environment contributes significantly to the health of individuals as well as communities (Houéto 2019). According to the analyzed research studies, the global unemployment rate is estimated to rise between 5.3 million in their low-end scenario and 24.7 million in their high-end scenario from a base level of 188 million last year 2019 (ILO 2020). As for 
the midrange scenario, the estimated rate of global unemployment is an increase of 13 million '7.4 million in high income countries' (ILO 2020).

When we look at the changed situation during the coronavirus pandemic from a social perspective. There is no doubt that the coronavirus Covid-19 will bring similar changes in thinking. People lost loved ones, jobs or businesses. And even though life has returned to normal, in future, apprehension for the possibility of infection will accompany people even during activities they took for granted in the past. The coronavirus has already forced companies to make an accelerated transition to the digital world, such as the boom in telemedicine and various patient ordering applications, which previously only slowly made their way to doctors and insurance companies.

As we have already mentioned, the economic crisis associated with the coronavirus will strike a powerful blow to financial welfare: the decline in production or the closure of enterprises and organizations in the public and private sectors will result in lower income, an increased debt, problems with mortgages, an rise of unemployment, etc. While these developments have inflicted substantial economic and social shocks as global production, consumption and employment levels dropped precipitously, they have also been associated with significant reductions in air pollution and greenhouse gas emissions. Reduction of the number of flights with their large greenhouse gas emissions can be also attributed to the positive environmental aspects of the reduction of tourist flows. Reduction in the number of hotels, public services and catering, transport trips, etc. can also be associated with the decrease in the environmental impact, variety of waste and pollution in tourist attractions. An increase in the segment of online employment, remote work outside offices, at home, etc., can lead to a reduction in urban pollution. A decrease in travel, especially personal vehicles, has a favourable environmental impact.

\section{Consumer behaviour in the era of the pandemic}

The outbreak has pushed consumers out of their normal routines. Consumers are adopting new habits and behaviours that many anticipate will continue in the long term. The most important factors which model the consumer's behavior in crisis are risk attitude and risk perception. Risk attitude reflects consumer's interpretation concerning to the risk content and how much he or she dislikes the content of that risk. Risk perception reflects the interpretation of the consumer of the chance of being exposed to the risk content. Hoon Ang et al. (2001) in his work discussed that these changes in consumption behaviour arising from an ecological crisis may be moderated by personality characteristics too. These characteristics of personality include such dimensions as the degree to which consumers are risk averse, value conscious and materialistic. Earlier studies were indicative of behavioral changes among consumer in times of crises with significant change in utility pattern. A study conducted by Flatters and Willmott (2009) identified few new trends during crisis which include simplification of demand because of limited offers during the crisis which tends to continue post-crisis where people buy simpler offering with great value. The study also reported that even rich people, postcrisis expressed dissatisfaction with excess consumption and focused on recycling and teaching their children simple and traditional values. Flatters and Willmott (2009) in their study proved that the impact of the recession on consumer attitudes and trends is critical. Some trends are advanced by the recession, while others are slowed or completely arrested. The most central trends in crisis include the demand for simplicity, which indicates that consumers seek uncomplicated, value-oriented products and services that simplify their lives and focus on the enactment of a company where consumers are outraged by the unlawful conduct and unethical company behaviour. 
The change in consumer behaviour during crisis times led authors' interest to explore consumer behaviour during COVID-19. When a certain level of income is achieved requirements for balancing all three components increase, so do requirements for the ecological factor of life (Bobylev 2017).

As this research shows (Yuen et al. 2020; Besson 2020), panic buying is commonly recognised as behaviour exhibited by consumers where they purchase unusually large amounts or an unusually varied range of products in anticipation of, during, or after a disaster or perceived disaster, or in anticipation of a large price increase or upstream shortage (Yuen et al. 2020). Panic buying often leads to large quantities of necessities and medical supplies being purchased from vendors, and vastly limiting or even eliminating availability such that individuals and vulnerable groups, including the elderly or poor, are prevented from accessing them as they would normally do (Besson 2020).

\section{Consumer behaviour in Slovakia during the pandemic of coronavirus}

In this part we look a bit closer at consumer behaviour in Slovakia during the pandemic of coronavirus. Slovakia people during the pandemic of COVID - 19, purchases moved rather to the online space. In March and April 2020, we saw record increases in online purchases, whether groceries, drugstores or household equipment. Only when buying food over the Internet, we have seen a 123 percent increase in the past two months. An interesting thing about online shopping is that so far Slovaks have literally avoided buying food over the Internet. Only the current situation forced them to take this step. According to the survey, two thirds of Slovaks could not yet imagine that they were ordering food online. It is the corona that has overcome these prejudices and therefore we expect that Slovaks will continue this trend even after the end of the pandemic (Buchláková 2020).
Research conducted by Kantar for Slovenská sporitelňa (April 2020) on a sample of 1,007 respondents showed that up to 80 percent of Slovaks want to continue with their shopping habits during the pandemic, especially in payments in stores by card or mobile phone. About half of the respondents found that online shopping saves time. At the same time, in the case of electronics or, for example, clothing, prices are often lower than in brick-and-mortar stores. Only seven percent of Slovaks say that they have a problem with online shopping and do not prefer it.

A global pandemic might be expected to create market and economic volatility, as well as to create vastly intensified consumer uncertainty and these effects have occurred during the current COVID-19 pandemic. As uncertainty moves to alter consumption patterns, consumer decision making has been further exacerbated by periods of government-enforced self-isolation for returning travellers or individuals who might have been exposed to the virus, as well as broader city- or country-wide periods of social distancing where people were largely restricted to their homes. Consumer behaviour began to change in a capacity more than the typical geographic presentation of purchases, to affect the timing, breadth, and volume of purchases (Loxton et al 2020). These examples suggest that dramatic changes are occurring in consumer buying behaviour and habits. Moreover, the lockdown conditions and social and physical distancing measures have continued to affect consumer purchase behaviour (Cranfield 2020) in the sense that consumers have moved to online grocery shopping. Evidence also shows that consumers tend to make healthier purchases when groceries are ordered using automated online shopping lists, thereby avoiding impulsive purchases (Charlebois 2020).

To sum up, consumers are deeply concerned about the impact of the coronavirus for socio-economic reasons. People are 
responding in a variety of ways and have differing attitudes, behaviours and purchasing habits. People across the globe are afraid as they strive to adapt to the new normal. Fear is running high as individuals contemplate what this crisis means for them, but more significantly, what it means for their families and friends, and society at large. Consumers in Slovakia are more concerned about the economic impact of COVID-19 than about their health. Consumers are responding to the crisis in a variety of ways. Some feel anxious and worried, panic-buying of staples and hygiene products. At the other extreme, some consumers remain indifferent to the pandemic and are continuing their business as usual, despite recommendations from government and health professionals.

\section{Consumer behaviour under the coronavirus disease (COVID-19) in the ecological context}

Even a few weeks ago, there was no one who would have stopped the whole world just like that, stopping day by day. The expected scenarios had been dreamed about for a long time by ecologists who are waiting for a change in the lifestyle of the current generations of people around the world. While the 2020 coronavirus pandemic disrupted the global economy and has been controlling the social behaviour of the human population, it is uncertain if it will mitigate the current climate crisis and help nature to return to a "healthier" state (Bavel et al. 2020) The coronavirus pandemic has altered human behaviour which gives rise to a question whether the associated economic and social impacts might outweigh disease impacts. The impact of the coronavirus on consumer behaviour can be viewed in three aspects: a) positive impact; b) negative impact; c) neutral impact.

Positive impact - Positive environmental consequences include the likely decrease in pollution in the coming years. The economic crisis, restriction or closure of enterprises, reduction of transport activity due to high gasoline prices in conditions of falling demand and living standards can improve the state of the environment (Bobylev 2020). An undoubted ecological good for the country and the whole planet can be the rejection of risky energy projects in the Arctic, in Northern regions, or territories with permafrost. Vast regions of our country unaffected by economic activity are an important stabilizer of the sustainability of the planet's biosphere. With low oil prices, transformation of the energy market into the buyer's market in the conditions of excess supply of traditional energy, it would be an economic adventure to heavily invest in new regions with huge production costs. There is a need in real energy-efficient restructuring of the economy, in which up to half of all energy resources can be saved by simple and cheap technologies; it is recognized even in government programs. Altered human behaviours also changed our interactions with other infectious agents. For example, in Hong Kong and Korea, the 2019-2020 the influenza epidemic period was shorter and the epidemic peak lower than in previous seasons (Cowling et al. 2020; Noh 2020), a phenomenon that has been echoed in the Southern Hemisphere (Servick 2020) For the next few years, beautiful natural landmarks can breathe more calmly - tourist flows will clearly weaken due to lower incomes, fear of being lockdown in a foreign country. The purified waters of the Venetian canals are regularly shown to us on television or on the internet. The observed tourist press (even the special term "overtourism" appeared) led to the degradation of a huge number of beautiful places on our planet (Bobylev 2020). As an external sign of such a press tens of millions of Chinese tourists around the world who suddenly found themselves in the middle class as a result of sharp growth in incomes and formed vast new tourist flows. It is estimated that the Chinese people spend about $\$ 400$ billion abroad annually.

Negative impact - Negative impacts could extend far into the future, as the COVID-19 pandemic has also interfered with and delayed environmental research, 
policy, management and education work. For example, research laboratories have been forced to end experiments, cancel travel, and shift research priorities (Servick et al. 2020) Problems with an increase in unemployment will have a negative impact on consumers. Once in a situation of shortage of money for the very subsistence, the population will not think about purchasing more expensive environmentally friendly food and water, purchase/rent housing in ecologically clean areas (Bobylov 2020) Apparently, there can be a kind of "individualization" of consumers. COVID-19 avoidance also has had negative effects on other species and the environment. For instance, in an effort to prevent infection, we are producing, using and discarding more single-use containers and personal protective equipment than ever before. For example, mask production has dramatically increased (e.g. 200 million produced per day in China) (Buck and Weinstein 2020), and often ends up littering natural spaces. Furthermore, many regulations banning plastic bag distribution have been suspended or delayed due to the pandemic (Buck and Weinstein 2020). Environmentally friendly phenomena such as the increasing role of public transport, the growth of car sharing, expansion of electric vehicles can face obstacles in the form of fears of the population to become infected with COVID and various viral analogues in case of pandemics or a significant spread of morbidity. Transport pollution can also be associated with the desire of the impoverished population to use their own cars with cheap unecological gasoline, increase in numbers of second-hand and obsolete vehicles. It is also possible to expect a reduction in visits to the public dining network (restaurants, cafes, etc.) due to epidemiological concerns, which, however, may be accompanied by an increase in domestic food volumes and food delivery from the same catering networks and stores (Bobylov 2020).

Neutral impact - Altered human behaviour has also had cascading impacts on wildlife that (at least from a human perspective) are neither positive nor negative. While peridomestic species struggled, lockdowns also caused wild animals to revert to behaviours and occupy habitats that they typically avoid in the presence of humans. Although no dolphins actually swam in Venice canals (Yoder 2020) wild Kashmiri goats fed on hedges in a deserted town in Wales, and white-crowned sparrows altered their songs in newly quieted urban areas. As the apex predator in many systems, humans profoundly impact animal movement, behaviour and habitat use, so it is not surprising that other species respond to our absence Indeed, the COVID-19 pandemic has created unique opportunities to study how humans impact the environment, and we are already seeing a surge in research in this area (Buck and Weinstein 2020). The Coronavirus crisis is showing that a change in behaviour in consumption, transportation, production, etc. It is possible with current technologies when the situation forces people to do so. There are far reaching implications of this. For example, distance working can be efficient. Use of office space under normal circumstances now seems to be highly inefficient in the sense that the same can be achieved without commuting time, congestion, transport emissions, etc. Travel is not a necessary input for the production function of the way we conduct business. Face to face businesses will suffer, in favour of remote, distance services.

\section{Conclusion}

The COVID-19 outbreak has slowed the pace and changed the daily lives of many consumers, and this is having a profound impact on the way we view personal hygiene, health and how we engage with our communities, friends and families. In the case of Covid-19, if people's behaviour had not changed with the social distancing, then most of the population would have been infected. By changing behaviour, many countries have managed to level off the infection rate or even to bring it down. All 
this will have a negative impact on consumer behaviour towards environmental quality of life. Once in a situation of shortage of money for the very subsistence, the population will not think about purchasing more expensive environmentally friendly food and water, purchase/rent housing in ecologically clean areas. What will be the ecological impact of the pandemic? This is not easy to predict, especially due to the lack of historical references. The environmental crisis is the result of human activity, driven by convenience and the lust for profit; we turned a blind eye to the deteriorating indicators of our ecosystem, the financial crisis was a response to overheated economic indicators. The Covid-19 crisis has lasted for only a few months; today, nobody knows what the world economy will look like in 3 or 6 months. One thing is certain, the economic crisis will be long-lasting and extremely painful, unemployment is still rising. This makes it all the more important for the communities of countries affected by the pandemic to prepare for a return to sustainable growth, taking into account, inter alia, the ecological and digital transformation and drawing all the lessons from the current crisis. The Covid-19 pandemic has changed the way we work and rest, has turned upside down the old patterns and ways of using public and private spaces; closed for weeks in our own homes and offices, we are learning to live anew; in the post-COVID-19 world, we want to live safely, healthily, and especially comfortablythe topic of sustainable housing is becoming more relevant than ever before. It is now up to us whether, while returning to normality, we will miss another opportunity offered by sustainable construction, or whether, by drawing conclusions, we will begin to shape our environment in the most responsible way possible.
Consumers purchase habits are changing due to the COVID-19 outbreak. Consumer priorities have become centred on the most basic needs, increasing the demand for hygiene, cleaning and staples products soaring, while non-essential categories slump. The factors that influence brand decisions are also changing as a "buy local" trend accelerates. Digital commerce has also seen a boost as new consumers are migrating online for grocery shopping - a rise that is likely to be sustained post-outbreak. In times like these, our need for the basic necessities of life takes precedence. It comes as no surprise that personal health is the top priority for the consumers we surveyed, followed by the health of friends and family. Food and medical security, financial security and personal safety were other leading priorities. Local perspectives, while the rich countries are expecting swift economic recovery along with environmental progress and reduced impacts (Hepburn et al. 2020), the pandemic is clearly aggravating the vulnerabilities of traditional and small populations in developing nations, including indigenous people living in or around conservation units (Hockings et al. 2020). While some positive actions have arisen, such as food sharing and collaborative communities, in some places the lack of tourist dollars has driven local people to hunt wild animals. While the impacts of regulated tourism are reduced in these areas, illegal hunting activities and opportunistic extractive industries potentially increase (Buckley 2020). Therefore, the economic disparities that exacerbate environmental problems deserve more attention and policymakers should consider the guidelines prepared by conservation scientists (Evans et al. 2020), creating effectively and equitably managed systems (Hockings et al. 2020). 


\section{Bibliography}

Arksey, Hilary, and Lisa O’Malley. 2005 "Scoping studies: towards a methodological framework." International Journal of Social Research Methodology 8(1): 19-32. https://doi.org/10.1080 /1364557032000119616.

Besson, Emilie K. 2020. COVID-19 (Coronavirus): Panic Buying and Its Impact on Global Health Supply Chains. Accessed June 16, 2020. https:// blogs.worldbank.org/health/covid-19-coronaviruspanic-buying-and-its-impact-global-healthsupply-chains.

Blackwell, Roger, Paul W. Miniard, and James F. Engel. 2006. Consumer behavior. Mason: Thomson/ South-Western.

Bloomberg News. 2020. "Coronavirus Outbreak." Accessed August 4, 2020. https://www.bloomberg. com/coronavirus.

Bobylev, Sergey N.2017. „Sustainable development: paradigm for the future. Mirovaya ekonomika i mezhdunarodnye otnosheniya." 3(61): 107-113. https:// doi.org/10.20542/0131-2227-2017-61-3-107-113.

Bobylev, Sergey N. 2020. "Environmental consequences of COVID-19 on the global and Russian economics." Population and Economics 4(2): 43-48. https://doi.org/10.3897/popecon.4.e53279.

Buck, Julia C., and Sara B. Weinstein. 2020. „The ecological consequences of a pandemic." 2020. Bioloogy Letters 16(11): 20200641. http://dx.doi. org/10.1098/rsbl.2020.0641.

Buckley, Ralf. 2020. "Conservation implications of COVID19: Effects via tourism and extractive industries." Biological Conservation vol. 247: 108640. http://dx.doi.org/10.1016/j. biocon.2020.108640.

Buchláková, Lenka. 2020. “Korona mení nákupné správanie Slovákov. Každý štvrtý sleduje pôvod potravín, zvýšila sa citlivost' na ceny." Accessed August 4, 2020. https://www.slsp.sk/ sk/aktuality/2020/6/11/korona-meni-nakupnespravanie-slovakov-kazdy-stvrty-sleduje-povodpotravin-zvysila-sa-citlivost-na-ceny.

CAMS (Copernicus Atmosphere Monitoring Service). 2020. "Surface concentrations of nitrogen dioxide in Europe.” Accessed August 4, 2020. https:// atmosphere.copernicus.eu/data.

Charlebois, Sylvain. 2020. Why COVID-19 Will Change Canadian Grocery Industry Forever: Expert. Accessed October 20, 2020. https://www. retail-insider.com/retail-insider/2020/03/whycovid-19-will-change-the-food-industry-forever/. Chinazzi, Matteo, Jessica T. Davis, Marco Ajelli, Corrado Gioannini, Maria Litvinova, Stefano Merler, Ana Pastore y Piontti, Kunpeng Mu, Luca Rossi, Kaiyuan Sun, Cecile Viboud, Xinyue Xiong, Hongjie Yu, Elizabeth M. Halloran, Ira M. Longini Jr., and Alessandro Vespignani. 2020. "The Effect of Travel Restrictions on the Spread of the 2019 Novel Coronavirus (COVID-19) Outbreak." Science 368(6489): 395-400. https:// doi.org/10.1126/science.aba9757.

Cowling, Benjamin J., Sheikh Taslim Ali, Tiffany W. Y. Ng, Tim K. Tsang, Julian C. M. Li, Min Whui Fong, Qiuyan Liao, Mike Y. W. Kwan, So Lun Lee, Susan S. Chiu, et al. 2020. „Impact assessment of nonpharmaceutical interventions against coronavirus disease 2019 and influenza in Hong Kong: an observational study." Lancet Public Health 5(5): E279-E288. DOI:https://doi. org/10.1016/S2468-2667(20)30090-6.

Cranfield, John A. L. 2020. „Framing consumer food demand responses in a viral pandemic." Canadian Journal of Agricultural Economics 60: 151-156. http://doi.org/10.1111/cjag.12246.

Evans, Olaniyi. 2020. "Socio-economic impacts of novel coronavirus: The policy solutions." BizEcons Quarterly 7: 3-12.

Feng, Cong, and Scott Fay. 2020. "Store closings and retailer profitability: A contingency perspective." Journal of Retailing 96(3): 411-433. https://doi. org/10.1016/j.jretai.2020.01.002.

Flatters, Paul, and Michael Willmott. 2009. "Understanding the postrecession consumer." Harvard Business Review 87(7/8): 64-72. Accessed August 20, 2020. https://hbr.org/2009/07/ understanding-the-postrecession-consumer.

Forster, Paul Whitfield, and Tang Ya. 2005. "The role of online shopping and fulfilment in the Hong Kong SARS crisis." In Proceedings of the 38th Annual Hawaii International Conference on System Sciences, edited by Ralph H. Sprague, 271a-271a. Los Alamitos: IEEE Computer Society Press.

Goldman, Arieh. 2001. "The transfer of retail formats into developing economies: the example of China." Journal of Retailing 77(2): 221-242.

Graham-Harrison, Emma. 2020. "What coronavirus lockdowns have meant around the world." The 
Guradian, March 18, 2020. https://www. theguardian.com/world/2020/mar/18/what-acoronavirus-lockdown-might-mean-for-london.

Hallsworth, Alan. 2013. "Food retailing." In The Handbook of Food Research, edited by Anne Murcott, Warren Belasco, and Peter Jackson, 275292. New York: Bloomsbury Publishing.

Hamilton, Rebecca, Mittal Chiraag, Anuj Shah, Debora V. Thompson, and Vladas Grickevicius. 2019. "How Financial Constraints Influence Consumer Behavior: An Integrative." Journal of Consumer Psychology 29(2): 285-305. https://doi. org/10.1002/jcpy.1074.

Hedgecoe, Guy, et al. 2020. "Coronavirus Capital by Capital: How are Europeans coping with shutdown?" BBC News, March 26, 2020. https:// www.bbc.co.uk/news/world-europe-52025553.

Hepburn, Cameron, Brian O'Callaghan, Nicholas Stern, Joseph Stiglitz, Dimitri Zenghelis. 2020. „Will COVID-19 fiscal recovery packages accelerate or retard progress on climate change?" Oxford Review of Economic Policy 36(Issue Supplement_1): S359-S381. https://doi.org/10.1093/oxrep/graa015.

Hockings, Marc, et al. 2020. „Covid-19 and protected and conserved areas." Parks 26(1): 7-24. https://doi. org/10.2305/IUCN.CH.2020.PARKS-26-1MH.en.

Hoon Ang, Swee, Peng Sim Cheng, Elison A. C. Lim, and Siok Kuan Tambyah. 2001. "Spot the difference: Consumer responses towards counterfeits." Journal of Consumer Marketing 18(3): 219-235. https://doi.org/10.1108/07363760110392967.

Houéto, David. 2019 "The social determinants of emerging infectious diseases in Africa." MOJ Public Health 8(2): 57-63.

ILO (International Labour Organization). "COVID-19 and the world of work: Impact and policy responses (March 18, 2020).” ILO Monitor 2020. Accessed November 18, 2020. https://www. ilo.org/wcmsp5/groups/public/---dgreports/--dcomm/documents/briefingnote/wcms_738753. pdf.

Ipsos.com. 2020. "Over half of Britons believe the Government was too slow to enforce lockdown." Accessed August 4, 2020. https://www.ipsos. com/ipsos-mori/en-uk/over-half-britons-believegovernment-was-too-slow-enforce-lockdown.

Levac, Danielle, Heather Colquhoun, and Kelly K. O’Brien. 2010. „Scoping studies: advancing the methodology." Implementation Science 5(69). https://doi.org/10.1186/1748-5908-5-69.

Liang, Fengxia, and Gerhard Litscher. 2020. "COVID-19 (Coronavirus Disease-19): Traditional Chinese Medicine including Acupuncture for Alleviation-A Report from Wuhan, Hubei Province in China." OBM Integrative and Complementary Medicine 5(1): 1-4. https://doi.org/10.21926/obm. icm.2001009.

Loxton, Mary, Robert Truskett, Brigitte Scarf, Laura Sindone, George Baldry, and Yinong Zhao. 2020. "Consumer Behaviour during Crises: Preliminary Research on How Coronavirus Has Manifested Consumer Panic Buying, Herd Mentality, Changing Discretionary Spending and the Role of the Media in Influencing Behaviour." Journal of Risk Financial Management 13(8): 166. https:// doi.org/10.3390/jrfm13080166.

Noh, Ji Yun, Hye Seong, Jin Gu Yoon, Joon Young Song, Hee Jin Cheong, and Woo Joo Kim. 2020. "Social distancing against COVID-19: implication for the control of influenza." Journal of Korean medical science 35(19): e182. https://doi. org/10.3346/JKMS.2020.35.E182.

Peters, Micah, Christina M. Godfrey, Hanan Khalil, Patricia Mcinerney, Cassia Baldini Soares, and Deborah Parker. 2017. "Guidance for the Conduct of JBI Scoping Reviews." International Journal of Evidence-Based Healthcare 13(3): 141-146.

Rubinstein, Peter. 2020. "Why grocery shelves won't be empty for long." Accessed August 4, 2020. https://www.bbc.com/worklife/article/20200401covid-19-why-we-wont-run-out-of-food-duringcoronavirus.

Servick, Kelly, Adrian Cho, Giorgia Guglielmi, Gretchen Vogel, and Jennifer Couzin-Frankel. 2020. „Updated: labs go quiet as researchers brace for long-term coronavirus distribution." Accessed August 18, 2020. https://www.sciencemag.org/ news/2020/03/updated-labs-go-quiet-researchersbrace-long-term-coronavirus-disruptions.

Servick, Kelly. 2020. „How will COVID-19 affect the coming flu season? Scientists struggle for clues." Accessed August 18, 2020. https://www. sciencemag.org/news/2020/08/how-will-covid-19affect-coming-flu-season-scientists-struggle-clues. Schiffman, Leon, Håvard Hansen, and Leslie Lazar Kanuk. 2008. Consumer Behaviour: A European Outlook. London: Pearson Education. 
Schneider, Maria Cristina, and Gustavo Machado 2018. "Environmental and socioeconomic drivers in infectious disease." The Lancet Planetary Health 2(5): e198-e199. https://doi.org/10.1016/ S2542-5196(18)30069-X.

Solomon, Michael R. 2011. „Consumer behavior: Buying, having and being." Pearson 14(2): 116-124.

Stallworth, P. 2008. "Consumer behaviour and marketing strategic." International Journal of Management and Commerce Innovations 2(1): 44-52.

Valaskova, Katarina, Katarina Kramarova, and Viera Bartosova. 2015. „Multi criteria models used in Slovak consumer market for business decision making." Procedia Economics and Finance 26: 174-182. https://doi.org/10.1016/ s2212-5671(15)00913-2.

Van Bavel, Jaj J., Katherine Baicker, Paulo S. Boggio, Valerio Capraro, Aleksandra Cichocka, Mina Cikara, Molly J. Crockett, Alia J. Crum, Karen M.
Douglas, and James M. Druckman, et al. 2020. "Using social and behavioural science to support COVID-19 pandemic response." Nature Human Behaviour 4: 460-471. https://doi.org/10.1038/ s41562-020-0884-z.

Vysekalová, Jitka. 2011. Chování zákazníka: jak odkrýt tajemstvi "černé skř́iňky”. Praha: Grada.

WHO. 2020. "Coronavirus." Accessed August 4, 2020. https://www.who.int/health-topics/ coronavirus\#tab=tab_1.

Yoder, Kate. 2020. Is nature all healed now? A look at the pandemic's best meme. Accessed November 18, 2020. https://grist.org/climate/is-nature-allhealed-now-a-look-at-the-pandemics-best-meme/. Yuen, Kum Fai, Xuegin Wang, Fei Ma, and Kevin X. Li. 2020. "The Psychological Causes of Panic Buying Following a Health Crisis." International journal of environmental research and public health 17(10): 3513. https://doi.org/10.3390/ijerph17103513. 